$12-2015$

\title{
An Evaluation of the Genetic Structure of Mapleleaf Mussels (Quadrula quadrula) in the Lake Erie Watershed
}

\author{
Wendy L. Paterson \\ Central Michigan University \\ Traci A. Griffith \\ Central Michigan University \\ Robert A. Krebs \\ Cleveland State University, r.krebs@csuohio.edu \\ Lyubov E. Burlakova \\ SUNY Buffalo State \\ David T. Zanatta \\ Central Michigan University
}

Follow this and additional works at: https://engagedscholarship.csuohio.edu/scibges_facpub

Part of the Biology Commons

How does access to this work benefit you? Let us know!

\section{Recommended Citation}

Paterson, Wendy L.; Griffith, Traci A.; Krebs, Robert A.; Burlakova, Lyubov E.; and Zanatta, David T., "An Evaluation of the Genetic Structure of Mapleleaf Mussels (Quadrula quadrula) in the Lake Erie Watershed" (2015). Biological, Geological, and Environmental Faculty Publications. 89.

https://engagedscholarship.csuohio.edu/scibges_facpub/89

This Article is brought to you for free and open access by the Biological, Geological, and Environmental Sciences Department at EngagedScholarship@CSU. It has been accepted for inclusion in Biological, Geological, and Environmental Faculty Publications by an authorized administrator of EngagedScholarship@CSU. For more information, please contact library.es@csuohio.edu. 


\title{
An evaluation of the genetic structure of mapleleaf mussels (Quadrula quadrula) in the Lake Erie watershed
}

\author{
Wendy L. Paterson, Traci A. Griffith, Robert A. Krebs, Lyubov E. Burlakova, David T. Zanatta
}

\section{Introduction}

Freshwater pearly mussels in the family Unionidae are large bivalves that live in the sediments of rivers, streams, and lakes worldwide, with over 300 species in North America (Graf and Cummings, 2007) and over 40 species native to the Great Lakes watershed (Graf, 2002; Metcalfe-Smith et al., 1998; Strayer and Jirka, 1997). These long-lived molluscs often survive for decades (Haag, 2012) and have a unique life cycle. While most bivalves have free-living larvae, unionid larvae are obligate parasites on fish. This adaptation, which enables mussels to move upstream over long distances, may also help maintain genetic diversity within spatially isolated populations.

Unionidae have experienced drastic declines in diversity and abundance throughout North America (Lydeard et al., 2004; Haag, 2012). In 1986, Dreissena polymorpha (Pallas, 1771), a Ponto-Caspian native, was introduced into the Great Lakes region from ballast water of transoceanic ships (Hebert et al., 1989; Carlton, 2008). Shortly after occurred the introduction of Dreissena rostriformis bugensis (Andrusov, 1897), another Ponto-Caspian region native (Mills et al., 1993). Both dreissenid species are highly competitive epifaunal filter feeders that attach to hard surfaces, including the hard shells of unionids, using byssal threads (Mackie, 1991). Live unionids may even be a preferred substrate (Burlakova et al., 2000; Mackie, 1991; Ricciardi et al., 1995), and fouling by dreissenids can impede filter feeding, reduce motility, and fitness and may be fatal when the number attached is high (Bowers and de Szalay, 2007; Haag et al., 1993; Mackie, 1991; Ricciardi et al., 1995).

The decline in unionid abundance and local extirpations (Schloesser et al., 2006; Schloesser and Nalepa, 1994) is likely to reduce gene flow among species composing the remaining assemblage. In the western basin of Lake Erie, Herdendorf (1987) reported 35 unionid species, including Quadrula quadrula (Rafinesque, 1820), although this species was apparently rare in the open waters prior to 1990 (Brown et al., 1938; Nalepa et al., 1991). More Q. quadrula could have existed prior to the present study, but most coastal unionid survey studies were recent (Crail et al., 2011) and suggest increases in this habitat generalist species that prefer muddy, mud mixed with sand, and cobble substrates (Metcalfe-Smith et al., 2000, 1998; Schloesser and Masteller, 1999; Bowers and de Szalay, 2004; Griffith, 2013; Prescott, 2014). 
As one of the more common species remaining in western Lake Erie, Q. quadrula could be used for making generalized assessments of genetic variation in rare, threatened, and endangered species remaining or returning to the lake. Understanding populations of common species is one way to develop a recovery plan for communities, as studies of population genetics help predict which populations are thriving and which populations are potentially experiencing inbreeding depression (Freeland, 2005), especially for species of similar life history strategies (Elderkin et al., 2007; Haag, 2012). Understanding dispersal routes is also critical, as historical patterns could indicate where modern barriers inhibit recolonization. For instance the Maumee River drainage has long been considered one of the likely post-glacial colonization routes for many unionid mussels into Lake Erie (Graf, 2002; Haag, 2012; Watters, 1995); however, there may be alternative origins (Krebs et al., 2013; Scott et al., 2014), suggesting a need to compare extant lake populations to those in the mouths of tributary streams.

Underlying dispersal patterns in Q. quadrula may match host fish movement. Possible host fish are thought to be flathead catfish (Pylodictis olivaris, Rafinesque, 1818) and channel catfish (Ictalurus punctatus, Rafinesque, 1818) (COSEWIC, 2006; Watters et al., 2009). The latter species is common in western Lake Erie (Bowers and de Szalay, 2007). Adequate gene flow could create an almost panmictic population even in a large lake (Krebs et al., 2015), while at the other extreme, low levels of genetic exchange or rare expansion events during colonization could create a genetically structured population. Analysis of microsatellite DNA loci can identify source or sink populations and relationships between geographic and genetic distance within the range of the species (Freeland, 2005). The major objectives of this study were to determine levels of genetic diversity and structure of Q. quadrula within and among Lake Erie (open embayments and drowned rivermouths) and its tributaries; and to identify whether divergence exists; and if so, whether patterns of variation better correspond to an island model (Wright, 1940) of variation or a steppingstone model of differentiation by distance (Kimura and Weiss, 1964).

\section{Methods and materials}

The American (U.S.A.) shore of Lake Erie was exhaustively surveyed in 2011 and 2012 (total of 132 sites from the Detroit River mouth to the Niagara River) for mussels, where a minimum of two person hours of search time (e.g., 4 searchers $\times 30 \mathrm{~min}$ ) was used at each site using several methods (visual, tactile, SCUBA, snorkel, raking; Zanatta et al.,
2015). Q. quadrula were located in large numbers only within the western basin (Fig. 1); this species has not been found alive in Canadian waters of Lake Erie in recent survey efforts (COSEWIC, 2006). From Lake Erie tributaries, sufficient samples of $Q$. quadrula for genetic analyses were obtained from three sites in the Maumee River, Ohio, from two sites pooled as a single location in the lower Grand River, Canada (upstream of Dunnville dam; Mathias and Zanatta, unpublished data; Galbraith et al., 2015), and from one site in the lower Huron River, Ohio (Table 1). Position and geographic distances among sites were calculated using the ARCMAPTM measuring tool in ARCGIS(R) software.

\section{Genetic data collection}

Mantle tissue was non-lethally excised from live mussels varying in size from $53 \mathrm{~mm}$ to $108 \mathrm{~mm}$ using biopsy techniques outlined in Berg et al. (1995). Each individual clip was stored in a $1.5 \mathrm{ml}$ microtube filled with $95 \%$ ethanol, which was placed in a $-20^{\circ} \mathrm{C}$ freezer within four days of collection. A fraction of the entire tissue sample (1-2 mg) was removed from each clip, and DNA was extracted and precipitated using an alcohol solution following the procedures of Sambrook et al. (1989).

Six microsatellite loci developed by Hemmingsen et al. (2009) for Quadrula fragosa (Conrad, 1835) were amplified using polymerase chain reaction (PCR) at conditions optimized for use with $Q$. quadrula (Table 2). Each reaction consisted of $1.0 \mu$ of working DNA (1:10 dilution from extracted DNA) mixed in $9.0 \mu \mathrm{L}$ of PCR cocktail [ $10 \times$ Taq buffer (Qiagen $^{\text {TM }}$ ), bovine serum albumin (BSA), deoxyribonucleotide triphosphate (dNTP), forward and reverse primers, $\mathrm{MgCl}_{2}$, and Taq (Qiagen ${ }^{\mathrm{TM}}$ )]. An Eppendorf Mastercycler ${ }^{\circledR}$ was used for DNA amplification with locus-specific settings. PCR products [including a positive (previously genotyped sample of known size) and negative control] were visualized electrophoretically under UV light on agarose gels to verify amplification.

Genotyping was conducted on an $\mathrm{ABI} 3730$ at the Natural Resources DNA Profiling \& Forensic Centre, Trent University (Peterborough, ON, Canada). Alleles based on fragment size classes were assigned using GENEMARKER $^{\text {TM }}$ (SoftGenetics LLC $($ ). The fragment sizes assigned by GENEMARKER were proofread and independently verified by two of the co-authors (WLP and TAG). The frequency of null alleles was estimated in MICROCHECKER v. 2.2.3 (van Oosterhout et al., 2004) using the Brookfield 1 method to incorporate excess in homozygosity and any individuals for which amplification failed (Brookfield, 1996). In

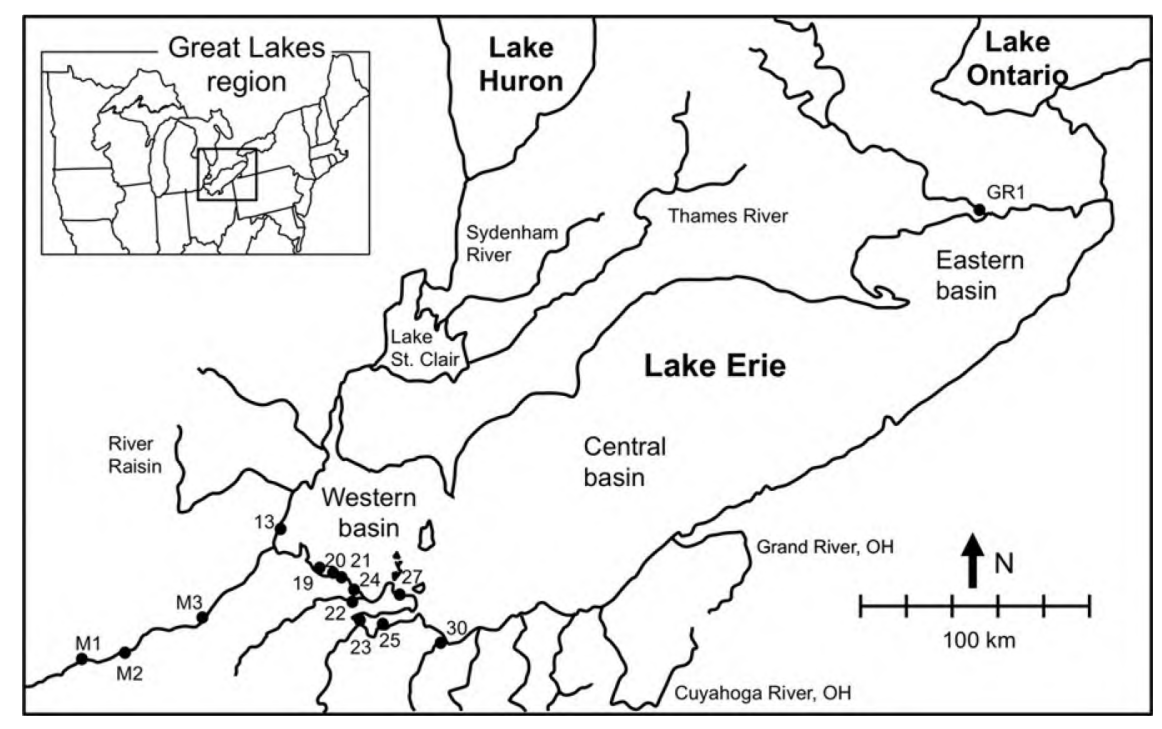

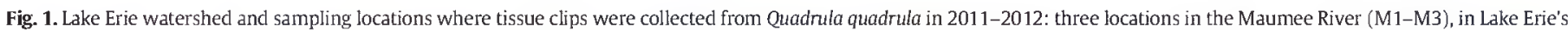

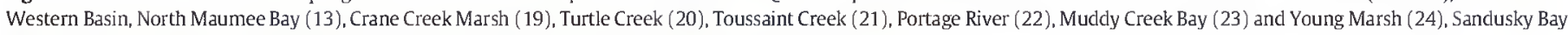
(25), East Harbor (27), Huron River, Ohio (30), and one location in the lower Grand River (GR1), Canada. 
Table 1

Sampling locations for Quadrula quadrula in 2011 and 2012 including location abbreviations (code), number of sites at each location, number of $Q$. quadrula found at each location, and the number of tissue clips obtained.

\begin{tabular}{|c|c|c|c|c|}
\hline $\begin{array}{l}\text { Sampling location } \\
\text { name (state or province) }\end{array}$ & $\begin{array}{l}\text { Location } \\
\text { code no. }\end{array}$ & $\begin{array}{l}\text { Number } \\
\text { of sites }\end{array}$ & $\begin{array}{l}\text { Number of Quadrula } \\
\text { quadrula within sites }\end{array}$ & $\begin{array}{l}\text { Number of } \\
\text { tissue samples }\end{array}$ \\
\hline Maumee River ${ }^{1}$ & M1-3 & 3 & 122 & 98 \\
\hline North Maumee Bay & 13 & 3 & 42 & 30 \\
\hline Crane Creek Marsh & 19 & 5 & 197 & 30 \\
\hline Turtle Creek & 20 & 4 & 84 & 30 \\
\hline Toussaint Creek & 21 & 4 & 158 & 30 \\
\hline Young Marsh & 24 & 2 & 23 & $30^{*}$ \\
\hline Portage River & 22 & 4 & 150 & 30 \\
\hline East Harbor & 27 & 2 & 2 & 2 \\
\hline Sandusky Bay & 25 & 14 & 34 & 14 \\
\hline Muddy Creek Bay & 23 & 17 & 105 & 30 \\
\hline Huron River & 30 & 3 & 8 & $12^{*}$ \\
\hline Grand River, Ontario ${ }^{I}$ & GR1 & 4 & 45 & 45 \\
\hline All location totals & 14 & 73 & 974 & 386 \\
\hline
\end{tabular}

1 Tissue samples from Mathias and Zanatta, unpublished data.

* Additional specimens found outside of 0.5 ha sites.

addition to calculating the frequency of null alleles MICROCHECKER also tested for errors in scoring as a result of peak stuttering or large-allele dropout (van Oosterhout et al., 2004).

Only locations with ten or more individuals with successful amplifications from minimally four of the six loci were used in non-individual based analyses. The probability of linkage disequilibrium was determined in GENEPOP 4.2 (Raymond and Rousset, 1995). Calculations of heterozygosity and tests for Hardy-Weinberg equilibrium were performed in GENALEX v. 6.5 (Peakall and Smouse, 2006), but all loci were used as common practice suggests the use of all microsatellite locus whether in or out of equilibrium (Selkoe and Toonen, 2006). Rarefacted allelic richness was calculated using FSTAT v 2.9 .3 (Goudet, $1995)$ to correct for variation in sample size (Manier and Arnold, 2005). Heterozygosity and rarefacted allelic richness were compared among sampling locations using Kruskal-Wallis tests (Kruskal and Wallis, 1952) in MINITAB 16 Statistical Software (2010).

Bayesian analyses of genetic structure were conducted in STRUCTURE v 2.3.4 (Pritchard et al., 2000) to compare the probability of a genotype for each individual being derived from a hypothesized set of genetic populations $(K)$, which can then be mapped geographically. Each analysis set parameters at 100,000 iterations after a burn-in period of 200,000 iterations; admixture and correlation among allele frequencies was assumed. Ten iterations of each $K$ were run for a maximum number of 26 populations ( 25 total number of sites sampled plus one) in STRUCTURE v 2.3.4 with and without the a priori geographic groupings indicated to determine if this had any effect on interpretation of population structure. Mean log likelihood was calculated using
STRUCTURE HARVESTER v 0.6.93 (Earl and von Holdt, 2012) to determine which $K$ best fit (Evanno et al., 2005) the STRUCTURE results.

Genetic differentiation was analyzed by two methods: Analysis of Molecular Variance (AMOVA; Excoffier et al., 1992; Huff et al., 1993; Peakall et al., 1995; Michalakis and Excoffier, 1996) and pairwise $F_{\text {ST, }}$ developed by Wright (1965). AMOVA was implemented in GENALEX to compare variation among the 12 sampling locations and the three geographic regions (Maumee River, Lake Erie, and Grand River). To determine if there was both genetic divergence among populations (e.g., $F_{\mathrm{ST}}$ ) and isolation by distance, as would be observed in steppingstone pattern for dispersal, we used a permutation algorithm (pairwise $F_{\mathrm{ST}}$ implemented in GENALEX) to examine site-specific differences both within and among regions (Allendorf and Luikart, 2007) and examined correlation between geographic and genetic distance in a Mantel test (Mantel, 1967). The Mantel test (Mantel, 1967) was implemented in GENEPOP comparing genetic distance in the form of linearized $F_{S T}$ $\left(\left[F_{S T} /\left(1-F_{S T}\right)\right]\right.$; calculated in GENALEX) to geographic distance. Geographic distances were calculated as the average shortest linear distance over water between sampling sites within each region. Linearized $F_{S T}$ was also used to create an unrooted neighbor-joining tree in TREEFIT (Kalinowski, 2009); explanatory power was based on the $R^{2}$ value, or the proportion of variation explained.

Evidence of recent bottlenecks was tested as observed excesses in heterozygosity within populations (Freeland, 2005) in BOTTLENECK v 1.2.02 (Cornuet and Luikart, 1996). These analyses were run twice, once for ten populations (eight western basin sampling locations, Maumee River, and Grand River) and once with three populations after pooling all individuals in each sampling region: Lake Erie, Maumee River, and Grand River. As recommended by Piry et al. (1999), each run was conducted using 10,000 iterations with the variance set at twelve and the probability set at $95 \%$. A signed-rank Wilcoxon test compared expected to observed heterozygosity among three models of evolution: Infinite Allele Model (I.A.M.), a Two Phase Model (T.P.M.), and a Stepwise Mutation Model (S.M.M.). Mode-Shift in allele frequencies was also examined to determine whether frequencies had the normal L-shaped distribution expected for stable populations, one with high frequencies of only a few alleles and many rare alleles, or after a genetic bottleneck, which can produce evenness of alleles following loss and/or increase in rare alleles (Piry et al., 1999).

\section{Results}

A total of 324 individuals from Lake Erie (211 individuals), the Maumee River (79 individuals), and the Grand River, Canada (34 individuals) were successfully amplified at a minimum four of the six loci. Over $90 \%$ of individuals used in the analyses successfully amplified at all six of the loci. No microsatellite loci were genetically linked.

Table 2

Amplification conditions for microsatellite loci optimized for Quadrula quadrula from Quadrula fragosa (Hemmingsen et al., 2009).

\begin{tabular}{|c|c|c|c|c|c|c|}
\hline & QfC4 & QfC114 & QfD102 & QfR9 & QfA1 12 & QfA130 \\
\hline GenBank accession no. & F]785632 & F]785634 & FJ785635 & FJ785639 & F]785630 & F]785631 \\
\hline Annealing temp. $\left(\mathrm{C}^{\circ}\right)$ & 59 & 59 & 51 & 63.5 & 59 & 55 \\
\hline Repeat motif & TACA & TACA & ATCT & $\mathrm{CA}$ & $\mathrm{CA}$ & TG \\
\hline Size range (bp) & $199-263$ & $204-232$ & $196-224$ & $207-231$ & $135-161$ & $176-280$ \\
\hline Number of alleles & 12 & 8 & 6 & 17 & 19 & 25 \\
\hline $\mathrm{dd}_{2} \mathrm{O}$ & $5.7 \mu \mathrm{l}$ & $5.6 \mu \mathrm{l}$ & $5.7 \mu \mathrm{l}$ & $5.6 \mu \mathrm{l}$ & $5.9 \mu \mathrm{l}$ & $5.7 \mu]$ \\
\hline $10 \times$ PCR buffer (contains $1.5 \mathrm{mM} \mathrm{MgCl} 2$ ) & $1 \mu \mathrm{L}$ & $1 \mu \mathrm{L}$ & $1 \mu \mathrm{L}$ & $1 \mu \mathrm{L}$ & $1 \mu \mathrm{L}$ & $1 \mu \mathrm{L}$ \\
\hline $\mathrm{MgCl}_{2}$ & $0.5 \mathrm{mM}$ & $0.5 \mathrm{mM}$ & $0.5 \mathrm{mM}$ & $0.5 \mathrm{mM}$ & $0.5 \mathrm{mM}$ & $0.5 \mathrm{mM}$ \\
\hline BSA & $0.2 \mathrm{mg} / \mathrm{ml}$ & $0.2 \mathrm{mg} / \mathrm{ml}$ & $0.2 \mathrm{mg} / \mathrm{ml}$ & $0.2 \mathrm{mg} / \mathrm{ml}$ & $0.2 \mathrm{mg} / \mathrm{ml}$ & $0.2 \mathrm{mg} / \mathrm{ml}$ \\
\hline dNTPS & $0.2 \mathrm{mM}$ & $0.2 \mathrm{mM}$ & $0.2 \mathrm{mM}$ & $0.2 \mathrm{mM}$ & $0.2 \mathrm{mM}$ & $0.2 \mathrm{mM}$ \\
\hline M13 universal primer & - & $0.4 \mathrm{mM}$ & - & $0.4 \mathrm{mM}$ & - & - \\
\hline Forward primer & $0.4 \mathrm{mM}$ & $0.1 \mathrm{mM}^{*}$ & $0.4 \mathrm{mM}$ & $0.1 \mathrm{mM}^{*}$ & $0.4 \mathrm{mM}$ & $0.4 \mathrm{mM}$ \\
\hline Reverse primer & $0.4 \mathrm{mM}$ & $0.4 \mathrm{mM}$ & $0.4 \mathrm{mM}$ & $0.4 \mathrm{mM}$ & $0.4 \mathrm{mM}$ & $0.4 \mathrm{mM}$ \\
\hline Taq & $0.5 \mathrm{U}$ & $0.5 \mathrm{U}$ & $0.5 \mathrm{U}$ & $0.5 \mathrm{U}$ & $0.5 \mathrm{U}$ & $0.5 \mathrm{U}$ \\
\hline DNA ( $5 \mathrm{ng})$ & $1 \mu \mathrm{l}$ & $1 \mu \mathrm{l}$ & $1 \mu \mathrm{l}$ & $1 \mu \mathrm{l}$ & $1 \mu$ & $1 \mu \mathrm{l}$ \\
\hline
\end{tabular}

* With M13 tag on $5^{\prime}$ end. 
MICROCHECKER calculated that null alleles were present at four of the six loci with probabilities of null alleles ranging from 0 to $7 \%$ at the seven loci used. No errors in scoring due to stutter or large allele dropout were found. Simulations suggest that null alleles minimally bias results when their frequencies are below 20\% (Dakin and Avise, 2004; Carlsson, 2008), which applied to all loci in this study. Significant deviations from Hardy-Weinberg (H-W) equilibrium occurred at 16 out of 72 locuspopulation combinations after Bonferroni's correction $(p=0.0042$, Table 3). Seven of the 12 sampling locations were out of equilibrium at locus R9 where all but the Huron River samples expressed lower than expected heterozygosity, suggesting null alleles at this one locus. The other nine differences were scattered throughout the results with four excesses in heterozygosity and five deficiencies, and therefore no overall difference was found when pooling across loci (Table 3). Likewise, sampling locations did not vary in mean rarefacted allelic richness (Kruskal-Wallis: $p=0.905$ and $p=0.998$ respectively, Table 3 ), and no recent bottleneck effects were indicated in any sensitivity model whether results were separated for each site or analyzed after grouping sites within the three regions (only Turtle Creek was significant ( $p=$ 0.016) after adjusting for multiple comparisons).

Among sampling locations, genetic variation in Q. quadrula was highly structured (Fig. 2). In the absence of assigning individuals to sampling locations, the entire data set had the highest likelihood of being divided into $K=4-6$ genetic clusters, all with similar mean log likelihoods $(\operatorname{Ln}[\operatorname{Pr}(\mathrm{X} \mid \mathrm{K})]=-3927.4$ for $\mathrm{K}=4, \operatorname{Ln}[\operatorname{Pr}(\mathrm{X} \mid \mathrm{K})]=-3926.9$ 3926.9 for $K=5, \operatorname{Ln}[\operatorname{Pr}(X \mid K)]=-3926.4$ for $K=6$ ). However, delineations of different groups were not visually distinct, as can be seen Fig. 2A where many of the individual bars are made of equal parts two or three clusters. When geographic distribution of individuals was added as a priori information, separation of genetic populations was pronounced with $\mathrm{K}=3(\operatorname{Ln}[\operatorname{Pr}(\mathrm{X} \mid \mathrm{K})]=-3800.0$, Fig. 2B). The three clusters were primarily comprised of individuals from the Grand River, Canada, another cluster of individuals of Maumee River origin, and a third as those individuals from Lake Erie.

The Lake Erie cluster showed some heterogeneity that corresponded to the edge localities. Individual samples from North Maumee Bay had almost the same probability of being assigned to the Maumee cluster (at $44 \%$ ) as they did for Lake Erie (56\%), suggesting intermediate multilocus genotypes (Fig. 2B). To the east, individuals from the Huron River, Ohio, possessed similarity with the Grand River cohort (68\% Lake Erie and 32\% Grand River). A related pattern, but to a lesser degree, was observed in the Sandusky Bay samples, which came from a location just west of the Huron River, also showed similarity with the Grand River Custer (Fig. 2). Other samples from within the western basin, most notably those from Toussaint Creek, Young Marsh, and the Portage River, possessed genotypes partially intermediate among all three clusters (Fig. 2B).

AMOVA results were congruent to those obtained from STRUCTURE analyses. When individuals were separated into twelve distinct sampling locations (Table 4 ) the global $F_{S T}$ was $0.118(p=0.0001)$, a similar value was obtained when defining just three regions, Maumee River, Lake Erie, and Grand River $\left(F_{S T}=0.102, p=0.0001\right)$. Moderate levels

Table 3

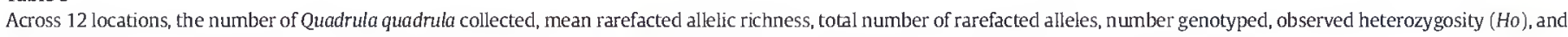
expected heterozygosity (He) Also, the number of rarefacted alleles, number genotyped, Ho, and He by locus and sampling location for Q. quadrula.

\begin{tabular}{|c|c|c|c|c|c|c|c|c|c|c|c|c|}
\hline & M1 & M2 & M3 & 13 & 19 & 20 & 21 & 24 & 22 & 23 & 30 & GR1 \\
\hline \# Collected & 36 & 35 & 27 & 30 & 30 & 30 & 30 & 30 & 30 & 30 & 12 & 65 \\
\hline $\begin{array}{l}\text { Mean allelic richness } \\
\text { Global }\end{array}$ & 5.667 & 5.500 & 5.833 & 5.833 & 5.167 & 5.167 & 6.667 & 7.167 & 6.000 & 4.667 & 3.333 & 5.000 \\
\hline Ave \# rarefacted alleles & 1.576 & $* *$ & ${ }^{* *}$ & 1.611 & 1.531 & 1.547 & 1.550 & 1.634 & 1.565 & 1.528 & 1.503 & 1.497 \\
\hline \# Genotyped & 27 & 28 & 24 & 26 & 27 & 28 & 27 & 28 & 27 & 29 & 10 & 34 \\
\hline Ho & 0.548 & 0.584 & 0.626 & 0.470 & 0.586 & 0.557 & 0.480 & 0.419 & 0.464 & 0.554 & 0.569 & 0.437 \\
\hline $\mathrm{He}$ & 0.539 & 0.563 & 0.575 & 0.594 & 0.518 & 0.533 & 0.538 & 0.619 & 0.550 & 0.516 & 0.456 & 0.482 \\
\hline \multicolumn{13}{|l|}{$\mathrm{C} 4$} \\
\hline \# Rarefacted alleles & 1.723 & $* *$ & $* *$ & 1.758 & 1.537 & 1.716 & 1.784 & 1.723 & 1.743 & 1.596 & 1.894 & 1.648 \\
\hline \# Genotyped & 25 & 27 & 23 & 19 & 17 & 16 & 27 & 24 & 23 & 21 & 6 & 22 \\
\hline $\mathrm{Ho}$ & 0.640 & 0.778 & 0.783 & 0.737 & 0.588 & 0.813 & 0.630 & 0.667 & $0.652^{*}$ & 0.524 & 1.000 & 0.727 \\
\hline $\mathrm{He}$ & 0.578 & 0.706 & 0.810 & 0.738 & 0.521 & 0.693 & 0.770 & 0.707 & 0.727 & 0.582 & 0.819 & 0.633 \\
\hline \multicolumn{13}{|l|}{ C114 } \\
\hline \# Rarefacted alleles & 1.638 & $* *$ & $* *$ & 1.577 & 1.573 & 1.467 & 1.592 & 1.590 & 1.577 & 1.592 & 1.556 & 1.789 \\
\hline \# Genotyped & 15 & 20 & 18 & 23 & 23 & 24 & 20 & 18 & 24 & 23 & 5 & 10 \\
\hline Ho & 0.733 & 0.850 & 0.889 & $0.522^{*}$ & 0.652 & 0.375 & $0.650^{*}$ & 0.500 & 0.417 & 0.609 & 1.000 & 0.400 \\
\hline $\mathrm{He}$ & 0.584 & 0.671 & 0.588 & 0.564 & 0.560 & 0.457 & 0.578 & 0.574 & 0.565 & 0.579 & 0.500 & 0.750 \\
\hline \multicolumn{13}{|l|}{ D102 } \\
\hline \# Rarefacted alleles & 1.000 & $* *$ & ** & 1.367 & 1.040 & 1.000 & 1.050 & 1.444 & 1.190 & 1.034 & 1.000 & 1.086 \\
\hline \# Genotyped & 1 & 0 & 0 & 18 & 25 & 24 & 20 & 19 & 20 & 29 & 10 & 34 \\
\hline $\mathrm{Ho}$ & 0.000 & 0.000 & 0.000 & 0.111 & 0.040 & 0.000 & 0.050 & $0.000^{*}$ & $0.100^{*}$ & 0.034 & 0.000 & 0.088 \\
\hline $\mathrm{He}$ & 0.000 & 0.000 & 0.000 & 0.356 & 0.039 & 0.000 & 0.049 & 0.432 & 0.185 & 0.034 & 0.000 & 0.084 \\
\hline \multicolumn{13}{|l|}{ R9 } \\
\hline \# Rarefacted alleles & 1.631 & $* *$ & $* *$ & 1.406 & 1.494 & 1.527 & 1.284 & 1.345 & 1.297 & 1.507 & 1.395 & 1.058 \\
\hline \# Genotyped & 24 & 24 & 23 & 17 & 24 & 23 & 19 & 21 & 21 & 28 & 10 & 34 \\
\hline $\mathrm{Ho}$ & 0.458 & 0.333 & 0.304 & $0.000^{*}$ & 0.750 & $0.870^{*}$ & $0.105^{*}$ & $0.095^{*}$ & $0.190^{*}$ & $0.821^{*}$ & 0.500 & $0.000^{*}$ \\
\hline $\mathrm{He}$ & 0.576 & 0.622 & 0.629 & 0.394 & 0.484 & 0.515 & 0.277 & 0.337 & 0.290 & 0.498 & 0.375 & 0.057 \\
\hline \multicolumn{13}{|l|}{ A 112} \\
\hline \# Rarefacted alleles & 1.725 & $* *$ & $* *$ & 1.744 & 1.719 & 1.708 & 1.753 & 1.777 & 1.774 & 1.747 & 1.857 & 1.698 \\
\hline \# Genotyped & 21 & 20 & 20 & 20 & 23 & 24 & 20 & 25 & 22 & 23 & 4 & 18 \\
\hline Ho & $0.857^{*}$ & 0.750 & 0.850 & 0.700 & 0.696 & 0.708 & 0.750 & $0.680^{*}$ & 0.591 & 0.783 & 0.750 & $0.778^{*}$ \\
\hline $\mathrm{He}$ & 0.766 & 0.660 & 0.709 & 0.725 & 0.703 & 0.694 & 0.734 & 0.762 & 0.756 & 0.731 & 0.750 & 0.679 \\
\hline \multicolumn{13}{|l|}{ A130 } \\
\hline \# Rarefacted alleles & 1.739 & $* *$ & $* *$ & 1.813 & 1.824 & 1.863 & 1.836 & 1.922 & 1.808 & 1.690 & 1.318 & 1.702 \\
\hline \# Genotyped & 20 & 24 & 14 & 16 & 19 & 19 & 26 & 21 & 12 & 18 & 6 & 27 \\
\hline Ho & 0.600 & 0.792 & $0.929^{*}$ & 0.750 & 0.789 & 0.579 & 0.692 & 0.571 & 0.833 & 0.556 & 0.167 & 0.630 \\
\hline $\mathrm{He}$ & 0.728 & 0.720 & 0.712 & 0.787 & 0.802 & 0.841 & 0.820 & 0.900 & 0.774 & 0.671 & 0.292 & 0.689 \\
\hline
\end{tabular}

* Observed heterozygosity out of Hardy-Weinberg equilibrium after Bonferroni's correction ( $\alpha=0.0042$ ).

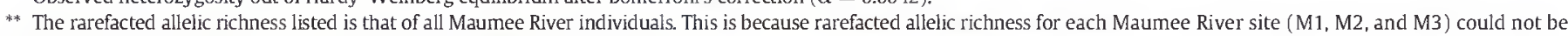
calculated as a result of limitation in amplifying locus D102 beyond site M1. 


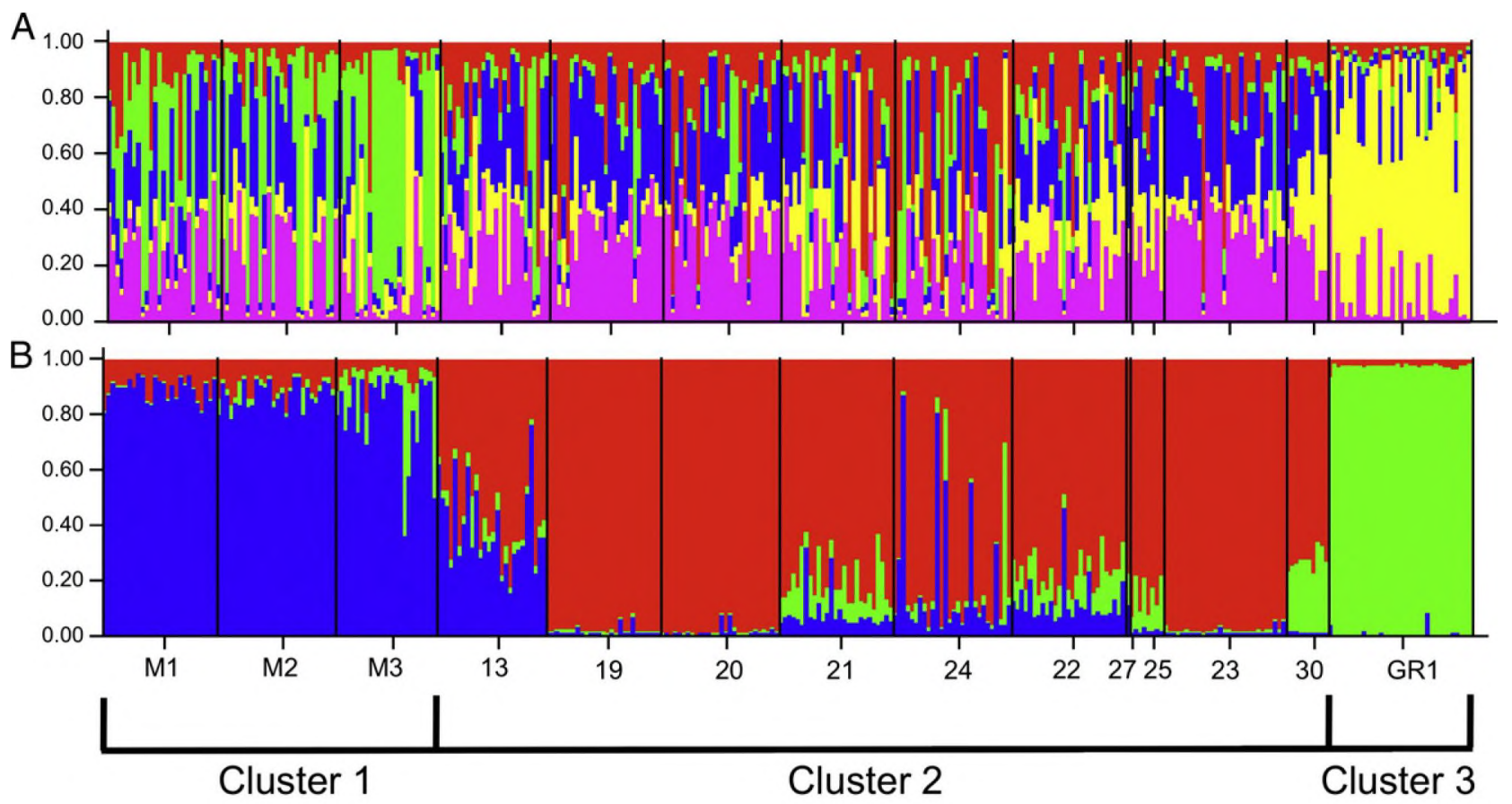

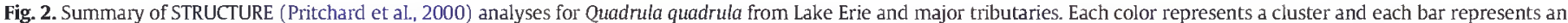

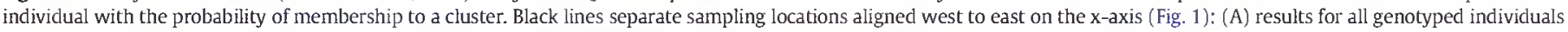
without assigning locality a priori $(K=5)$, and $(B)$ results with prior geographic information included in the analysis ( $K=3$ ).

of genetic differentiation were also suggested by pairwise $F_{S T}$ values (Maumee River \& Lake Erie, $F_{S T}=0.080$; Lake Erie and Grand River, $F_{S T}=0.111$; and Maumee $\&$ Grand rivers, $F_{S T}=0.204$ ).

The neighbor-joining topology constructed using TREEFIT (not shown) indicated a good fit with genetic distance $\left(R^{2}=0.930\right)$ and had three clusters of branches: Maumee River, Lake Erie, and Grand River, supporting the other methods used to determine genetic structure. The greatest branch length, which represents genetic distance, was between the Maumee and Grand River locations, Lake Erie was intermediate, and the Huron River lay between those of the Grand River and the Western Basin localities. Thus, using a Mantel test, a regression of geographic distance on genetic distance was significant $(p<0.0001)$ (Fig. 3).

\section{Discussion}

\section{Population structure}

The recent invasion of dreissenid mussels caused near extirpation of unionids but may not have had a currently observable genetic impact on the Q. quadrula populations within Lake Erie. A progressive change in multilocus genotypes extends between the Maumee River in the west, across Lake Erie, and to the Grand River, Canada, in the east, with differentiation among groups discrete, but not absolute. The Maumee River, which empties into western Lake Erie at Toledo, Ohio, is a known habitat of Q. quadrula (Clark and Wilson, 1912; Grabarkiewicz and Crail, 2006) and is considered a possible post-Pleistocene source of Q. quadrula for Lake Erie (Graf, 2002). Similar to the Maumee, the Grand River is a major tributary that possessed a diverse mussel community prior to the industrial age, and the persistence of $Q$. quadrula there suggests pollution tolerance (Metcalfe-Smith et al., 2000).

Evidence of admixture within Lake Erie populations indicates that both rivers may continue to function as sources of recolonization for Q. quadrula and points to a stepping-stone model of genetic structure for Q. quadrula in Lake Erie watershed (Wright, 1940; Kimura and Weiss, 1964). Clear regional genetic differentiation exists in the Lake Erie watershed, nonetheless a high degree of gene flow among neighboring locations is demonstrated in each of the analyses utilized (STRUCTURE outputs, AMOVA, pairwise tests of genetic differentiation, tests for isolation by distance, and the neighbor-joining analysis). The

Table 4

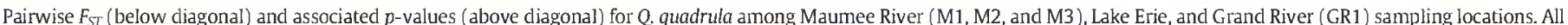
results are from an AMOVA run with 9999 permutations.

\begin{tabular}{|c|c|c|c|c|c|c|c|c|c|c|c|c|}
\hline & M1 & M2 & M3 & 13 & 19 & 20 & 21 & 24 & 22 & 23 & 30 & GR1 \\
\hline M1 & - & 0.4457 & 0.0068 & 0.0001 & 0.0001 & 0.0001 & 0.0001 & 0.0001 & 0.0001 & 0.0001 & 0.0001 & 0.0001 \\
\hline M2 & $0.0000^{*}$ & - & 0.1300 & 0.0001 & 0.0001 & 0.0001 & 0.0001 & 0.0001 & 0.0001 & 0.0001 & 0.0001 & 0.0001 \\
\hline M3 & $0.0208^{*}$ & $0.0069^{*}$ & - & 0.0001 & 0.0001 & 0.0001 & 0.0001 & 0.0001 & 0.0001 & 0.0001 & 0.0001 & 0.0001 \\
\hline 13 & 0.1028 & 0.1101 & 0.1079 & - & 0.0007 & 0.0026 & 0.0012 & 0.0718 & 0.4295 & 0.0001 & 0.0001 & 0.0001 \\
\hline 19 & 0.1969 & 0.2072 & 0.2079 & $0.0326^{*}$ & - & 0.4300 & 0.0001 & 0.0001 & 0.0026 & 0.4367 & 0.0006 & 0.0001 \\
\hline 20 & 0.1935 & 0.1996 & 0.1931 & $0.0264^{*}$ & $0.0000^{*}$ & - & 0.0001 & 0.0001 & 0.0003 & 0.1607 & 0.0001 & 0.0001 \\
\hline 21 & 0.1220 & 0.1210 & 0.1400 & $0.0303^{*}$ & 0.0391 & 0.0498 & - & 0.1078 & 0.0003 & 0.0001 & 0.0001 & 0.0001 \\
\hline 24 & 0.0834 & 0.0982 & 0.0957 & $0.0094^{*}$ & 0.0450 & 0.0486 & $0.0077^{*}$ & - & 0.0201 & 0.0001 & 0.0001 & 0.0001 \\
\hline 22 & 0.1349 & 0.1514 & 0.1361 & $0.0000^{*}$ & $0.0288^{*}$ & 0.0362 & 0.0378 & $0.0164^{*}$ & - & 0.0003 & 0.0001 & 0.0001 \\
\hline 23 & 0.2210 & 0.2344 & 0.2344 & 0.0526 & $0.0000^{*}$ & $0.0065^{*}$ & 0.0505 & 0.0642 & 0.0341 & - & 0.0060 & 0.0001 \\
\hline 30 & 0.2451 & 0.2645 & 0.2699 & 0.0848 & $0.0627^{*}$ & 0.0759 & 0.0828 & 0.0941 & 0.0832 & $0.0467^{*}$ & - & 0.0075 \\
\hline GR1 & 0.2951 & 0.3162 & 0.3249 & 0.1801 & 0.1624 & 0.1815 & 0.1457 & 0.1508 & 0.1786 & 0.1551 & $0.0376^{*}$ & - \\
\hline
\end{tabular}

* Indicates $F_{5 T}$ values are not significantly different from zero after Bonferroni's correction for multiple comparison $(\alpha=0.0005)$. 


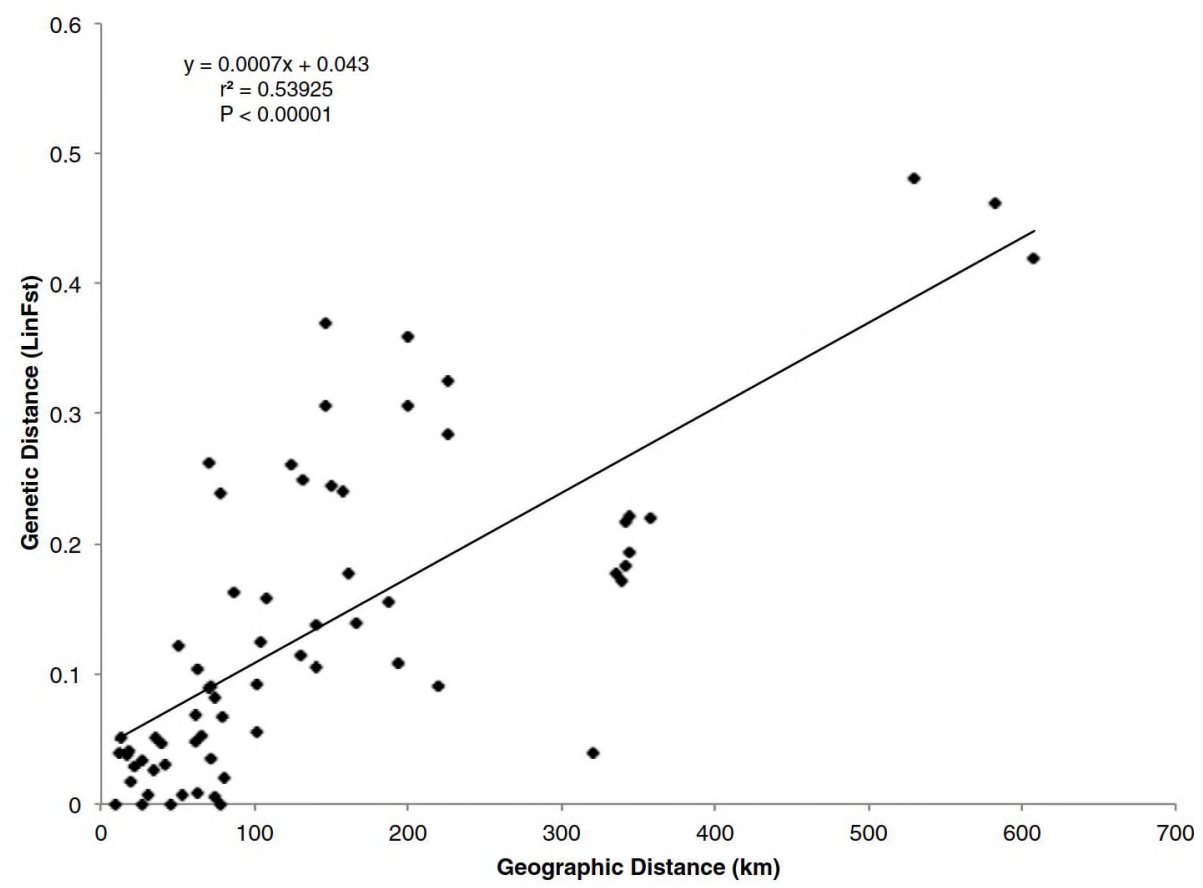

Fig. 3. Linear regression of geographic distance over water between sampling locations and genetic distance (linearized $F_{S T}$ ). p-Value calculated using a Mantel test (Mantel, 1967).

western basin sites clustered together geographically and did not show obvious genetic structure while pairwise $F_{S T}$ values were above 0.25 among Maumee River sites and the Grand River, indicating increasing differentiation among populations that are most geographically distant, as predicted by a stepping-stone model in contrast to islands models of isolation (Wright, 1940; Kimura and Weiss, 1964).

Unfortunately, the rarity of Q. quadrula in other Lake Erie tributaries limits testing further for similarities between $Q$. quadrula in the western portion of the watershed to Canada's Grand River. For example, Q. quadrula is likely extirpated from the Rocky River (Krebs and Rundo, 2005); it is rare in the Cuyahoga River (Smith et al., 2002); and Huehner et al. (2005) report its presence only in deep water just above the shipping channel in Ohio's Grand River. An explanation for the observed genetic structure may be found in the movement patterns in channel catfish (I. punctatus), the probable host for Q. quadrula in Lake Erie. Channel catfish can move sufficient distances to connect all three regions, but not to span the length of the lake (Hubley, 1963; Shrader et al., 2003). Zanatta and Wilson (2011) found evidence of a combined influence of both geographic distribution and host distribution on populations of Epioblasma triquetra (Rafinesque, 1820). No genetic information on I. punctatus is presently available even though they are a popular sport fish in Lake Erie. Channel catfish rank as the fifth most harvested species in the lake, but greater than $85 \%$ of the catch is caught in the western basin (ODW, 2012).

At local scales, dams located in both the lower Grand River at Dunnville, Ontario since 1829 (Bunt et al., 2000) and the in the Maumee River at Defiance and Grand Rapids, Ohio (Independence and Providence Dams), each may impede upstream fish movement (http:// www.dnr.state.oh.us/indpndam/tabid/747/Default.aspx). Note that STRUCTURE plots (Fig. 2) provided evidence of downstream admixture into the western basin and from the Grand River, but much less evidence of gene flow upstream in either river even though a fishway was constructed in 1994 in the Grand River to facilitate upstream fish dispersal (and thus mussel glochidia; Metcalfe-Smith et al., 2000). By contrasting population structure in the doubly-uniparental inheritance systems of mussel mitochondria, Krebs et al. (2013) found that dams and waterfalls consistently separated haplotype variants of femaleinherited forms, limited to the movement of glochidia, but not male inherited mtDNA haplotypes, which could also move downstream as spermatozeugmata (sperm balls).

\section{Genetic diversity}

While dreissenid mussels have been identified as a serious threat to unionid assemblages in the Great Lakes (Zanatta et al., 2002; Schloesser et al., 2006), their effects on the genetic diversity of $Q$. quadrula in Lake Erie, as well as on Pyganodon grandis (Say, 1829) and Lampsilis siliquoidea (Barnes, 1823) appear as yet small (Krebs et al., 2015; Rowe and Zanatta, 2015). However, we stress that all of these results may represent an overly optimistic situation for other unionids in Lake Erie. Only species with large populations have been tested, and most populations appear to have many alleles for which their frequencies remain in HardyWeinberg equilibrium (77.8\% locus-population pairs of Q. quadrula in this study), and allelic diversity of microsatellite loci was high.

Although there are no studies on genetic diversity of Q. quadrula in Lake Erie, Berg et al. (1998) assessed Q. quadrula using allozymes and concluded that they vary little across widely separated river systems. Later, Elderkin et al. (2008) examined variation in Elliptio dilatata (Rafinesque, 1820) and Actinonaias ligamentina (Lamarck, 1819) across even larger distances and similarly found clear effects of genetic isolation in mtDNA haplotypes. Separately, Elderkin et al. (2007) used mtDNA and allozymes to examine population structure of Amblema plicata (Say, 1817), and found decreasing genetic diversity in a northerly direction from the Mississippi drainage across to the Lake Erie drainage. A. plicata, like $Q$. quadrula, is considered to have an equilibrium life history strategy that could persist during disturbances and thrive once the disturbance subsides (Haag et al., 1993; Haag, 2012). Therefore, the Lake Erie drainage may be sufficiently small of scale not to expect large differences in genetic diversity based on microsatellites, yet differentiation was clear in $Q$. quadrula among sampling locations across the Lake Erie watershed.

\section{Management implications}

Rare, threatened, or endangered species have a greater risk of low genetic diversity and in turn are influenced more by differentiation, 
isolation, and genetic drift (Freeland, 2005). The low to moderate levels of differentiation of the relatively common Q. quadrula found in the western basin of Lake Erie indicates that uncommon unionid species in the same area may be in jeopardy of inbreeding depression. Likewise the more rare and imperiled species may show a disrupted steppingstone pattern in the Lake Erie watershed with lower connectivity across the lake and its tributaries, thus resulting in lower genetic diversity and greater population instability.

Haag et al. (1993) suggested that species belonging to the unionid tribes Amblemini and Quadrulini are less harshly affected by dreissenids in the western basin of Lake Erie and have generally higher survival rates than members of other unionid groups. Life histories often differ among these species, as equilibrium species like Q. quadrula have relatively long lifespans, late maturity, variable and delayed fecundity, and moderate to large body size (Haag, 2012). Several other equilibrium species still occur in the coastal areas, but at lower abundance: A. plicata, Fusconaia flava (Rafinesque, 1820), Pleurobema sintoxia (Rafinesque, 1820), and Quadrula pustulosa (Lea, 1831) (Sherman et al., 2013; Crail et al., 2011). Recent findings using L. siliquoidea [a member of the tribe Lampsilini with a periodic life history (Haag, 2012)] in Lake St. Clair showed similar results to those found in this study with little evidence of impact of the dreissenid invasion on genetic diversity, despite major demographic effects (Rowe and Zanatta, 2015). The two other more common species remaining in Lake Erie are P. grandis (Say, 1829) and Leptodea fragilis (Rafinesque, 1820) (Crail et al., 2011; Bryan et al., 2013), both of which are short-lived and highly fecund opportunistic species (Haag, 2012) that may quickly recover naturally from river mouths (Prescott, 2014). The life histories of various mussels in the Lake Erie watershed are likely to result in differing genetic structure post the initial extirpation by dreissenid mussels. Although equilibrium species, such as $Q$. quadrula, may be able to retain populations longer, they cannot repopulate quickly and are at greater risk than opportunistic species should additional stressors occur.

Without further degradation of the current populations and based on $Q$. quadrula as a representative species, a diverse gene pool may remain should unionids repopulate vacated habitat in Lake Erie. As Kimura and Weiss (1964) expected in the stepping stone model, population structure is most evident when genetic distance is examined in relation to geographic distance; and if Q. quadrula of the Lake Erie watershed are indeed in a stepping-stone pattern of dispersal, then geographically distant populations remain connected to each other via intermediate locations in the western basin. Unfortunately, dreissenids are not likely to decline soon to densities permissive for large scale, lakewide recovery of the unionid community in the open waters of Lake Erie.

\section{Acknowledgments}

US Fish and Wildlife Service - Great Lakes Fish and Wildlife Restoration Act, provided funding for this project (Project No.: 30191-A-G152). Graduate assistantships awarded by Central Michigan University College of Science and Technology, also assisted advancement of this project. For their professional collaboration and collection of data we would like to thank the following people: Dr. A. Karatayev from Buffalo State College; T. Prescott and M. Begley from Cleveland State University; G. Longton, J. Bateman, M. Shackelford, and D. Okon from DTE Energy Corporation; Dr. F. de Szalay, Dr. D. Kapusinski, M. Hickin, K. Shreve, J. Martin, and B. Brdek from Kent State University; M. Walsh, B. Meyer, and R. Miller from Pennsylvania Natural Heritage Program; Dr. T. Crail and Dr. J. Bossenbroek from University of Toledo; and D. Schloesser from USGS Great Lakes Science Center. For their support, guidance, and collection of data we would like to thank, M.W. Scott, L. Kolich, L. Adams, J. Bergner, M. Rowe, E. Bertram, S. Parker, and P. Mathias from Central Michigan University; and friend, B. Muller. This paper is contribution \#52 of the Central Michigan University Institute for Great Lakes Research.

\section{References}

Allendorf, F.W., Luikart, G., 2007. Conservation and the Genetics of Populations. Blackwell Publishing Ltd., Oxford, UK

Berg, D.J., Haag, W.R. Guttman, S.I., Sickel, J.B., 1995. Mantle biopsy: a technique for nondestructive tissue-sampling of freshwater mussels. J. N. Am. Benthol. Soc. 14, $577-581$.

Berg, D.J., Cantonwine, E.G., Hoeh, W.R., Guttman, S.l., 1998. Genetic structure of Quadrula quadrula (Bivalvia: Unionidae): little variation across large distances. J. Shellfish Res. $17,1365-1373$

Bowers, R., de Szalay, F.A., 2004. Effects of hydrology on unionids (Unionidae) and zebra mussels (Dreissenidae) in a Lake Erie coastal wetland. Am. Midl. Nat. 151, 286-300.

Bowers, R. de Szalay, F.A., 2007. Fish predation of zebra mussels attached to Quadrula quadrula (Bivalvia: Unionidae) and benthic molluscs in a Great Lakes coastal wetland. Wetlands 27, 203-208.

Brookfield, J.F.Y., 1996. A simple new method for estimating null allele frequency from heterozygote deficiency. Mol. Ecol. 5, 453-455.

Brown, C., Clark, C., Gleissen, B., 1938. The size of certain naiades from western Lake Erie in relation to shoal exposure. Am. Midl. Nat. 19,682-701.

Bryan, N.J., Florence, C.V., Crail, T.D., Moorhead, D.L., 2013. Freshwater mussel community response to warm water discharge in western Lake Erie. J. Gt. Lakes Res. 39, 449-454.

Bunt, C.M., Cooke, S.J., McKinley, R.S., 2000. Assessment of the Dunnville fishway for passage of walleyes from Lake Erie to the Grand River, Ontario. ]. Gt. Lakes Res. 26, $482-488$.

Burlakova, L.E., Karatayev, A.Y., Padilla, D.K., 2000. The impact of Dreissena polymorpha (Pallas) invasion on unionid bivalves. Int. Rev. Hydrobiol. 85, 529-541.

Carlsson, J., 2008. Effects of microsatellite null alleles of assignment testing. J. Hered. 99, $616-623$.

Carlton, J.T., 2008. The zebra mussel Dreissena polymorpha found in North America in 1986 and 1987. J. Gt. Lakes Res. 34, 770-773.

Clark, H.W., Wilson, C.B., 1912. The Mussel Fauna of the Maumee River. U.S. Bureau of Fisheries Report No. 757 (72 pp.)

Cornuet, J.M. Luikart, G. 1996. Description and power analysis of two tests for detecting recent population bottlenecks from allele frequency data. Genetics $144,2001-2014$.

COSEWIC, 2006. COSEWIC assessment and status report on the Mapleleaf Mussel Ouddrula quadrula (Saskatchewan-Nelson poputation and Great Lakes-Western St. Lawrence population) in Canada. Committee on the Status of Endangered Wildlife in Canada, Ottawa.

Crail, T.D., Krebs, RA., Zanatta, D.T., 2011. Unionid mussels from nearshore zones of Lake Erie. J. Gt. Lakes Res. 37, 199-202.

Dakin, E.E., Avise, J.C., 2004. Microsatellite null alleles in percentage analysis. Heredity 93 , 504-509.

Earl, D.A., von Holdt, B.M., 2012. STRUCTURE HARVESTER: a website and program for visualizing STRUCTURE output and implementing the Evanno method. Conserv. Genet. Resour. 4, 359-361.

Elderkin, C.L. Christian, A.D. Vaughn, C.C., Metcalfe-Smith, J.L., Berg D. 2007. Population genetics of the freshwater mussel, Amblema plicata (Say 1817) (Bivalvia: Unionidae): evidence of high dispersal and post-glacial colonization. Conserv. Genet. 8, 355-372.

Elderkin, C.L., Christian, A.D., Metcalfe-Smith, J.L., Berg, D.J., 2008. Population genetics and phylogeography of freshwater mussels in North America, Elliptio dilatata and Actimonaias ligamentina (Bivalvia: Unionidae). Mol. Ecol. 17, 2149-2163.

Evanno, G., Regnaut, S., Goudet, J., 2005. Detecting the number of clusters of individuals using the software STRUCTURE: a simulation study. Mol. Ecol. 14, 2611-2620.

Excoffier, L., Smouse, P.E., Quattro, J.M., 1992. Analysis of molecular variance inferred from metric distances among DNA haplotypes: application to human mitochondrial DNA restriction data. Genetics 131, 479-491.

Freeland, J.R., 2005. Molecular Ecology. John Wiley and Sons Ltd., Chichester, West Sussex, England.

Galbraith, H.S., Zanatta, D.T., Wilson, C.C., 2015. Comparative analysis of riverscape genetic structure in rare, threatened and common freshwater mussels. Conserv. Genet. 16 , $845-857$.

Goudet, J., 1995. FSTAT (Version 1.2): a computer program to calculate F-statistics. 1. Hered. $86,485-486$

Grabarkiewicz, J., Crail, T.D., 2006. Freshwater Mussels of the Maumee Drainage. Special Publication funded by the USEPA, USFWS, OEEF, and OEPA 2nd ed.

Graf, D.L., 2002. Historical biogeography and late glacial origin of the freshwater pearly mussel (Bivalvia: Unionidae) faunas of Lake Erie. North America. Harv. University Mus. of Comparative Zoology, Occasional Pap. on Mollusks 6, pp. 175-211.

Graf, D.L., Cummings, K.S., 2007. Review of the systematics and global diversity of freshwater mussel species (Bivalvia: Unionoida). J. Molluscan Stud. 73, 291-314

Griffith, T.A., 2013. Relating genetic and species diversity metrics of unionid mussels (Bivalvia: Unionidae) across variable habitats in the coastal regions of western Lake Erie Thesis (M.S.) Central Michigan University.

Hadg, W.R., 2012. North American Freshwater Mussels: Natural History, Ecology, and Conservation. Cambridge University Press, New York, New York.

Haag, W.R., Berg, D.J., Garton, D.W., Farris, J.L., 1993. Reduced survival and fitness in native bivalves in response to fouling by the introduced zebra mussel (Dreisseno polymorpha) in western Lake Erie. Can. J. Fish. Aquat. Sci. 50, 13-19.

Hebert, P.D.N., Muncaster, B.W., Mackje, G.L., 1989. Ecological and genetic studies on Dreissena polymorpha (Pallas): a new mollusc in the Great Lakes. Can. J. Fish. Aquat. Sci. 46, 1587-1591.

Hemmingsen, A.H., Roe, K.]., Serb, J.M., 2009. Isolation and characterization of nine microsatellite markers for the endangered winged-mapleleaf mussel, Ouadrula fragosa (Bivalvia, Unionidae). Mol. Ecol. Resour. 9, 1460-1466. 
Herdendorf, C.E., 1987. The ecology of the coastal marshes of western Lake Erie: a community profile. Biological Report 85(7.9). United States Fish Wildlife Service, Washington, DC, USA.

Hubley, R.C., 1963. Movement of tagged channel catfish in the upper Mississippi River. Trans. Am. Fish. Soc. 92, 165-168.

Huehner, M.K, Krebs, R.A, Zimmerman, G., Mejia, M., 2005. The unionid mussel fauna of northeastern Ohio's Grand River. Ohio J. Sci. 105, 57-62.

Huff, D.R, Peakall, R, Smouse, P.E., 1993. RAPD variation within and among natural populations of outcrossing buffalograss [Buchloe dactyloides (Nutt.) Engelm.]. Theor. Appl. Genet. 86, 927-934.

Kalinowski, S.T., 2009. How well do evolutionary trees describe genetic relationships between populations? Heredity 102, 506-513.

Kimura, M., Weiss, G.H., 1964. The stepping stone model of population structure and the decrease of genetic correlation with distance. Genetics 49, 561-576.

Krebs, R.A., Rundo, L.J., 2005. Diversity of Unionidae in the Rocky River, Ohio. J. Freshw. Ecol. 20, 603-608.

Krebs, R.A., Borden, W.C., Evans, N.M., Doerder, F.P., 2013. Differences in population structure estimated within maternally and paternally inherited forms of mitochondria in Lampsilis siliquoidea (Bivalvia: Unionidae). Biol. J. Linn. Soc. 109, 229-240.

Krebs, R.A., Allen, B.D., Evans, N.M., Zanatta, D.T., 2015. Mitochondrial DNA structure of Pyganodon grandis (Bivalvia: Unionidae) from the Lake Erie watershed and selected locations in its northern distribution. Am. Malacol. Bull. 33, 1-9.

Kruskal, W.H., Wallis, W.A., 1952. Use of ranks in one-criterion variance analysis. J. Am. Stat Assoc. 47, 583-621.

Lydeard, C., Cowie, R.H., Ponder, W.F., Bogan, A.E., Bouchet, P., Clark, S.A., Cummings, K.S., 2004. The global decline of nonmarine mollusks. Bioscience 54, 321-330.

Mackie, G.L., 1991. Biology of the exotic zebra mussel, Dreissena polymorpha, in relation to native bivalves and its potential impact in Lake St. Clair. Hydrobiologia 219, 251-268.

Manier, M.K. Amold, S.J., 2005. Population genetic analysis identifies source-sink dynamics for two sympatric garter snake species (Thamnophis elegans and Thamnophis sirtalis). Mol. Ecol. 14, 3965-3976.

Mantel, N., 1967. The detection of disease clustering a generalized regression approach. Cancer Res. 27, 209-220.

Metcalfe-Smith, J.L., Staton, S.K., Mackie, G.L., Lane, N.M., 1998. Changes in the biodiversity of freshwater mussels in the Canadian waters of the lower Great Lakes drainage basin over the past 140 years. ]. Gt Lakes Res. 24, 854-858.

Metcalfe-Smith, J.L., Mackie, G.L., Di Maio, J., Staton, S.K., 2000. Changes over time in the diversity and distribution of freshwater mussels (Unionidae) in the Grand River, southwestern Ontario. ]. Gt. Lakes Res. 26, 445-459.

Michalakis, Y., Excoffier, L., 1996. A generic estimation of population subdivision using distances between alleles with special reference for microsatellite loci. Genetics $142,1061-1064$

Mills, E.L., Dermott, R.M., Roseman, E.F., Dustin, D., Mellina, E., Conn, D.B., Spindle, A.P. 1993. Colonization, ecology and population structure of the "quagga" mussel (Bivalvia: Dreissenidae) in the lower Great Lakes. Can. J. Fish. Aquat. Sci. 50, 2305-2314.

Minitab 16 Statistical Software, 2010. Computer Software. Minitab, Inc., State College, PA (www.minitab.com).

Nalepa, T.F., Manny, B.A., Roth, J.C., Mozley, S.C., Schloesser, D.W., 1991. Long-term decline in freshwater mussels (Bivalvia: Unionidae) of the western basin of Lake Erie. J. Gt Lakes Res. 17, 214-219.

Ohio Division of Wildlife (ODW), 2012. Ohio's Lake Erie Fisheries, 2011. Annual status report Federal Aid in Fish Restoration Project F-69-P. Ohio Department of Natural Re sources, Division of Wildlife, Lake Erie Fisheries Units, Fairport and Sandusky (119 pp.)

Peakall, R., Smouse, P.E., 2006. GENALEX 6: genetic analysis in Excel. Population genetic software for teaching research. Mol. Ecol. Notes 6, 288-295.

Peakall, R., Smouse, P.E., Huff, D.R., 1995. Evolutionary implications of allozyme and RAPD variation in diploid populations of dioecious buffalograss Buchloe dactyloides. Mol. Ecol. 4, 135-148

Piry, S., Luikart, G., Cornuet, J.-M., 1999. BOTTLENECK: a computer program for detecting recent reductions in the effective population size using allele frequency data. J. Hered. $90,502-503$.
Prescott, T.J., 2014. Assessment of Freshwater Mussel Communities of Small Stream Mouths along Lake Erie. Thesis (M.S.) Cleveland State University.

Pritchard, J.K., Stephens, M., Donnelly, P., 2000. Inference of population structure using multilocus genotype data. Genetics 155, 945-959.

Raymond, M., Rousset, F., 1995. GENEPOP (version 1.2): population genetics software for exact tests and ecumenicism. J. Hered. 86, 248-249.

Ricciardi, A. Whoriskey, F.G., Rasmussen, J.B., 1995. Predicting the intensity and impact of Dreissena infestation on native unionid bivalves from Dreissena field density. Can. J. Fish. Aquat. Sci. 52, 1449-1461.

Rowe, M.T., Zanatta, D.T., 2015. Investigating the genetic variation and structure of a native unionid mussel in the Laurentian Great Lakes following an invasion of dreissenid mussels. Biol. Invasions 17, 351-364.

Sambrook, J., Fritsch, E.F., Maniatis, T., 1989. Molecular cloning Vol. 2. Cold Spring Harbor Laboratory Press, New York, pp. 14-19.

Schloesser, D.W. Masteller, E.C. 1999. Mortality of unionid bivalves (Mollusca) associated with dreissenid mussels (Dreissena polymorpha and D. bugensis) in Presque Isle Bay, Lake Erie. Northeast. Nat. 6, 341-352.

Schloesser, D.W., Nalepa, T.F., 1994. Dramatic decline of unionid bivalves in offshore waters of western Lake Erie after infestation by the zebra mussel, Dreissena polymorpha. Can. J. Fish. Aquat. Sci. 51, 2234-2242.

Schloesser, D.W., Metcalfe-Smith, J.L, Kovalak, W.P., Longton, G.D., Smithee, R.D., 2006 Extirpation of freshwater mussels (Bivalvia: Unionidae) following the invasion of dreissenid mussels in an interconnecting river of the Laurentian Great Lakes. Am. Midl. Nat. 155, 307-320.

Scott, M.W., Begley, M.T., Krebs, R.A. Zanatta, D.T., 2014. Mitochondrial DNA variation in the Eastern Pondmussel, Ligumia nasuta (Bivalvia: Unionoida) in the Great Lakes region. Walkerana 17, 60-67.

Selkoe, K.A., Toonen, R.J., 2006. Microsatellites for ecologists: a practical guide to using and evaluating microsatellite markers. Ecol. Lett. 9, 615-629.

Sherman, J.J., Murray, B.A., Woolnough, D.A., Zanatta, D.T., Uzarski, D.G., 2013. Assessment of remnant unionid assemblages in a selection of Great Lakes coastal wetlands. J. Gt. Lakes Res. 39, 201-210.

Shrader, T.M., Moody, B., Buckman, M., 2003. Population dynamics of channel catfish in Brownlee Reservoir and the Snake River, Oregon. N. Am. J. Fish. Manag. 23, 822-834.

Smith, D.C., Gates, M.A., Krebs, R.A., Tevesz, M.].S., 2002. A survey of freshwater mussels (Unionidae) and other molluscs in the Cuyahoga Valley National Park. Ohio Biol. Surv., Misc. Contrib. No. 8 (iv-31p.).

Strayer, D.L., Jirka., K.J., 1997. The pearly mussels of New York State. New York State Museum Memoir 26 (xiii-113 + 27 plates).

van Oosterhout, C., Hutchinson, W.F., Wills, D.P.M., Shipley, P., 2004. MICRO-CHECKER: software for identifying and correcting genotyping errors in microsatellite data. Mol. Ecol. Notes 4, 535-538.

Watters, G.T., 1995. Small dams as barriers to freshwater mussels (Bivalvia, Unionoida) and their hosts. Biol. Conserv. 75, 79-85.

Watters, G.T., Hogarth, M.A., Stansbery, D.H., 2009. The Freshwater Musse]s of Ohio. The Ohio State University, Sheridan Books, Hunt Valley, Maryland.

Wright, S., 1940. Breeding structure of populations in relation to speciation. Am. Nat. 74 232-248.

Wright, S., 1965. The interpretation of population structure by F-statistics with special regard to systems of mating. Evolution 19, 395-420.

Zanatta, D.T., Wilson, C.C., 2011. Testing congruency of geographic and genetic population structure for a freshwater mussel (Bivalvia: Unionoida) and its host fish. Biol. J. Linn Soc. $102,669-685$

Zanatta, D.T., Mackie, G.L., Metcalfe-Smith, J.L., Woolnough, D.A, 2002. A refuge for native freshwater mussels (Bivalvia: Unionidae) from Impacts of the exotic zebra mussel (Dreissena polymorpha) in Lake St Clair. J. Gt. Lakes Res. 28, 479-489.

Zanatta, D.T. Bossenbroek, J., Burlakova, L.E. Crail. T. de Szalay, F., Griffith, T.A. Kapusinski, D., Karatayev, A.Y., Krebs, R.A. Meyer, E.S., Paterson, W.L, Prescott, T.J. Rowe, M.T., Schloesser, D.W., Walsh, M.C., 2015. Distribution of native musse (Unionidae) assemblages in coastal Lake Erie, Lake St. Clair, and connecting channels, twenty-five years after the dreissenid invasion. Northeast. Nat. 22, 223-235. 